\section{Baron Palace Myths: A Horror Tourism Destination in Egypt}

Shaimaa Nagib, Ghada Hammoud, Hosam Refai and Manal Bourhan

\section{Abstract}

Simply Dark Tourism are those that relate to death, whether the destinations are linked to untimely or violent deaths. Dark tourism can enlighten an understanding of how contemporary societies deal with and represent their significant dead. Dark tourism is concerned with death and dying through its social scientific study; Dark tourism tells us more about life. Horror or Ghost tourism, includes any form of travel or leisure that involves encounters with or learning about ghosts or hauntings; it is simply a tour for places believed to be haunted - ghost sightings, haunted rooms or any other type of adventures. In addition, whether it is called ghost tourism, paranormal tourism or even haunted tourism, this type of travel takes you to places that are in some way thought to be unusual.

Since the last quarter of the twentieth century, there had been an increase in the organization of trips to Horror tourist sites as Dracula's castle or Vampires legend. Therefore, the study focuses on how to apply Niche tourism as Horror tourism into Baron Palace distinctively. Hence, the Baron Palace could be the first site to endorse such a genre of horror scenarios not implemented in Egypt before. The research attempts to conclude how applying horror tours inside the Baron Palace using the rumors and mysteries related to the site. Additionally, it is one of the unique Horror and mystery touristic sites because of its rare design, large space and stories about the Baron himself and his family. Thus, it would be a unique adventure and experience when visiting the Palace because it combines secrets with information. Additionally, the audience will be part of the historical legend for the location, Horror Tourism; The Thrill of Fear without danger.

\section{Keywords}

Horror Tourism, Dracula`s Castle, Niche Tourism and Baron Palace.

\section{Introduction}

There are various forms of Niche tourism as Adventure tourism, Agri-tourism, Cruise tourism, Culture/heritage tourism, Ecotourism, Educational tourism, Indigenous tourism, Medical tourism, Music tourism, Religious tourism, Sports tourism, Volunteer tourism ${ }^{1}$, Photographic tourism, Geo tourism, Gastronomic Tourism, Rural tourism, Festival tourism, Religious tourism, Research tourism, Wildlife tourism, Virtual tourism, Dark tourism and Horror tourism². For instance, sites of tragedy and death have become increasingly attractive to tourists and tourism studies. Furthermore, everything from places of past wars,
car accidents, murderers' homes, Myths and murder tours, have been captured under the theme of Horror Tourism according to Stone $(2006)^{3}$. Consequently, Dark Tourism ${ }^{4}$ is the act of travelling to sites and exhibitions that have actual death or suffering as the principal theme. Likewise. Horror tourism involves travel to places connected with unusual death and agony or to places where tragedies or historically noteworthy deaths had occurred and so far, continue to affect our lives.

\section{The growing interest in Dark Tourism}

Evidence suggests that contemporary tourists are increasingly travelling to destinations associated with death, suffering, and

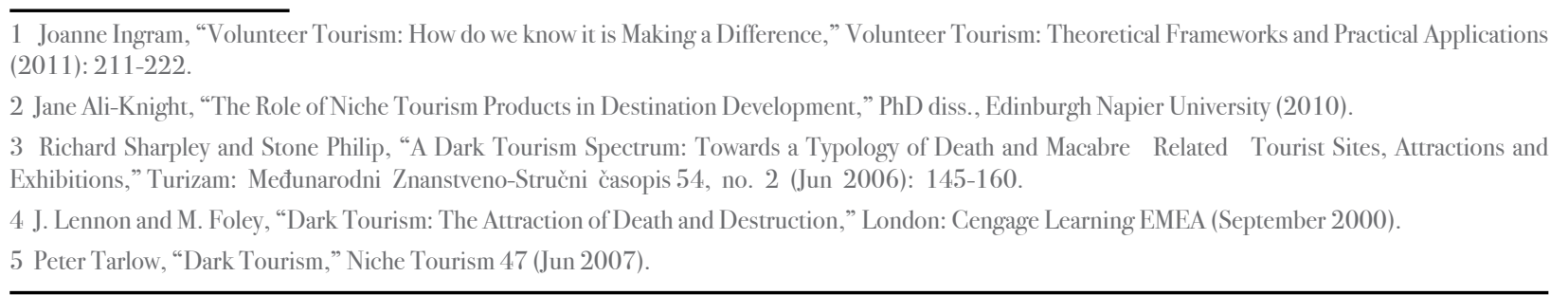

sites of dark events6. Curious visitors flock to the scene of the disaster instead of being away from it, in addition, visitor take souvenirs and photographs; it seemed to be driven by nosiness7. Some examples of pastimes Dark tourism as public executions, graveyards, slavery heritage, atrocities, prisons, and horror sites8. Hence, things that could not be explained were given a supernatural explanation a few hundred years ago. In recent years, the research focus has shifted to understanding reasons behind visiting places of death and suffering. Otherwise, the motivations of visitants have received scrutiny where they are discovered to be a mixture of interest in death, curiosity, desire for learning, remembrance of victims and understanding of tragic events. As a result, it is appropriate to describe visitors to places of death or suffering as Dark tourists9. However. attempts to explain why tourists visit such places usually relied on speculations or assumptions. Overall, tourists visit dark spots with a wide variety of purposes 10

- A thrill and risk seeking lure tourists who like adventure and excitement.

- A need for being acquainted with the knowledge of places that had an experienced tragedy like mass murder.

- Self-discovery and learning about such sites to boast of them later.

- The urge to visit sites that have immortal memories linked with people or even stories about haunted mansions ${ }^{11}$.

\section{The Horror tourism index of Europe's most visited tourism cities:}

The following table lists European tourist cities.

\section{Table (1): Europe's top tourist cities:}

\begin{tabular}{|l|l|l|l|}
\hline Ranking & City & $\begin{array}{l}\text { Number. Of } \\
\text { Visitors }\end{array}$ & Website (English version) \\
\hline 1st & Romania & 500000 & http://www.bran-castle.com/ \\
\hline 2nd & London & 13266 & http://www.visitlondon.com/ \\
\hline 3rd & Amsterdam & 11689 & http://www.iamsterdam.com/en/visiting \\
\hline 4th & Rome & 5468 & http://www.turismoroma.it/?lang=en \\
\hline 5th & Paris & 4512 & http://en.parisinfo.com// \\
\hline 6th & Prague & 4298 & http://www.prague.eu/en \\
\hline 7th & Istanbul & 3149 & \\
\hline 8th & Vienna & 3076 & http://www.wien.info/en \\
\hline 9th & Barcelona & 2820 & http://www.turismedebarcelona.net/ \\
\hline 10th & Milan & 775 & http://www.visitamilano.it/turismo_en// \\
\hline 11th & Venice & 167 & http://www.venice-tourism.com/en/visit-venice.html \\
\hline
\end{tabular}

Source: Raymond Powell et al, "Dark Cities: A dark tourism index for Europe's tourism citites, based on the analyssis of DMO websites. "International Journal

6Richard Sharpley and Stone Philip, Eds. “The Darker Side of Travel: The Theory and Practice of
Dark Tourism," Channel View Publications (August 2009)

Chenguang Zheng and Lee Colgin. Laura, "A Neuronal Mechanism for the Recall of Bad Events"

8 Duncan Marson, "From Mass Tourism to Niche Tourism," Research Themes for Tourism (2011): 1-1

(10

10 Rami Isaac and Platenkamp Vincent, "Dionssus Versus Apollo: An Uncertain Search for Identity Through Dark Tourism-Palestine as a Case Study" In

11 Warren John Carter, Storyteller, Interpreter, Evangelist. Baker Books (Jun 2006). 
People usually attempt to visit sites associated with mysteries, unusual stories, or paranormal instances ${ }^{12}$. Additionally, some museums, and exhibitions are dedicated particularly for that objective' ${ }^{13}$. Thus, horrifying characters like Vampires and Werewolves, all have a factual history behind them, a unique example of which is Dracula's myth which became an international brand at Transylvania in Romania (Table, 2).

Romania used this myth to present its heritage strongly as a Horror tourism destination, where Dracula's site is associated with both fiction and history. It is hard to categorize Dracula as a particular type of tourism that can be categorized as cultural tourism, literary tourism, movie-induced tourism or Horror tourism and heritage tourism ${ }^{14}$. Hence, mixing historical sites with fictional stories triggered the curious feeling among people who want to know the truth. Dracula castle was not always a foremost tourist destination before the 1970s, but in the 20th and 21 st century, the site has been developed to attract more tourist and gain more profits ${ }^{15}$. Today, Transylvania became an iconic destination for a unique type of Niche Tourism, which is known as Horror tourism that attracted Dracula and vampire admirers's

\section{Table (2): Horror Tourism in Romania (Dracula Castle):}

\begin{tabular}{|l|l|l|l|l|l|}
\hline Country & Number of Visitors Per year & $\begin{array}{l}\text { Number of Tourists in the } \\
\text { whole country Per year }\end{array}$ & $\begin{array}{l}\text { Sites } \\
\mathrm{P} \mathrm{r} \mathrm{i} \mathrm{c} \mathrm{e}\end{array}$ & $\begin{array}{l}\text { Service in } \\
\text { sites }\end{array}$ & $\begin{array}{l}\text { Contribution to } \\
\text { the economy }\end{array}$ \\
\hline $\begin{array}{l}\text { Romania/ } \\
\text { Dracula Castle }\end{array}$ & $\begin{array}{l}835,116 \text { tourists. Over } \\
60 \% \text { of the visitors were } \\
\text { foreigners, in 2017 }\end{array}$ & $12,706,133$ in 2017 & $\$ 9.42$ & Nothing & $\begin{array}{l}6 \text { million Euro in } \\
2017\end{array}$ \\
\hline
\end{tabular}

\section{bran-cassle-turnover-visitor-2017.}

Today Horror tourism is a well-established type of tourism that could be practised not only in Romania but also in cities as Edinburgh and York that have a long history of offering ghost tours. In addition, Whitby in England, Salem and New Orleans are a focus for those interested in the supernatural adventures ${ }^{17}$.

Egypt has many similar heritage places that could be used for the first time as horror tourism, where Baron Palace is one of them. It contains the elements that allow its re-use in the same way as Dracula's site ${ }^{18}$. Thus, all the visits will aim to discover whether these are mere fantasies, facts or both ${ }^{19}$

\section{Reasons for choosing the Baron Palace as a Horror site:}

- The location is easily accessible, near the airport and the palace is the highlight of Heliopolis.

- The design is unique, thus, attracting visitors especially those who are interested in the style of the Indian culture.

- The area is huge and can be used for various activities like selling.

- Available opportunities to finance the reuse of the Baron Palace due to its importance

- The Horror museum inside the Palace exhibits artefacts relating to the tragedy.

The Horror tour through visual reality inside the palace using different interpretations and Myths related to the site

12 Duncan Light, "The Dracula Dilemma: Tourism, Identity and the State in Romania," Routledge (March 2016

13 Kirsten Bos et al., "A draft genome of Yersinia pestis from victims of the Black Death." Nature 478, no. 7370 (October 2011): 506-510.

14 David Inglis and Holmes Mary, "Highland and Other Haunts: Ghosts in Scottish Tourism," Annals of Tourism Research 30, no. 1 (January 2003): 50-6.

15 Matthew Beresford, "From Demons to Dracula: The Creation of the Modern Vampire Myth, Reaktion Books (December 2008).

16 Athinodoros Chronis, "Between Place and Story: Gettysburg as Tourism Imaginary," Annals of Tourism Research 39, no. 4 (October 2012): 1797-1816. 17 Annette Pritchard and Morgan Nigel, “Mood Marketing"-the New Destination Branding Strategy: A A Case Study of Wales' The Brand, Journal of Vacation Marketing 4 , no. 3 (July 1998): 215-229.

18 Adina Nicoleta Candrea et al., “Marketing The Count's Way: How Dracula's Myth Can Revive Romanian Tourism," Bulletin of The Transylvania University

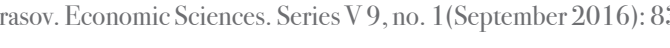

19 Abeer Attia et al,., "The Role of Dark Tourism in Developing The Demand for The Egyptian Tourist Product," Tourism Research Institute 12, no. 1
(December 2015): 3-14. 160

\section{The History and Design}

The Palace of Baron Empain exists at Heliopolis in Cairo as a unique architectural masterpiece and for a long time the palace was uninhabitable. ${ }^{20}$. Baron Empain had chosen for his palace a particular style unrelated to any local traditional architecture. He commissioned two famous French artists to design his palace, Alexandre Marcel, for the exterior design and his associate, Georges-Louis, for its elaborate interior ${ }^{21}$. Marcel drew inspiration of the Palace design from the Hindu architecture of Angkor Wat; it is an ancient temple complex in Cambodia. Edward Empain's palace hosted many prestigious guests such as the Belgian King Albert I. The palace was built in 1911; it was said that the Baron had enjoved watching the pyramids from his palace's terrace $^{22}$. The Palace is surrounded by a large oarden from all sides as seen in the layout. It is composed of a basement, oround floor and a roof and it consists of two floors above the ground, two other floors underground, and a tower built in the middle of them $^{23}$. On the walls of the palace, there are statues made of marble for wonderful dancers from India and amazing elephants. studded with small pieces of Belgium glass. It is interesting to note that the palace was designed so as not to lose sight of the su the whole day, (See Photo 1).

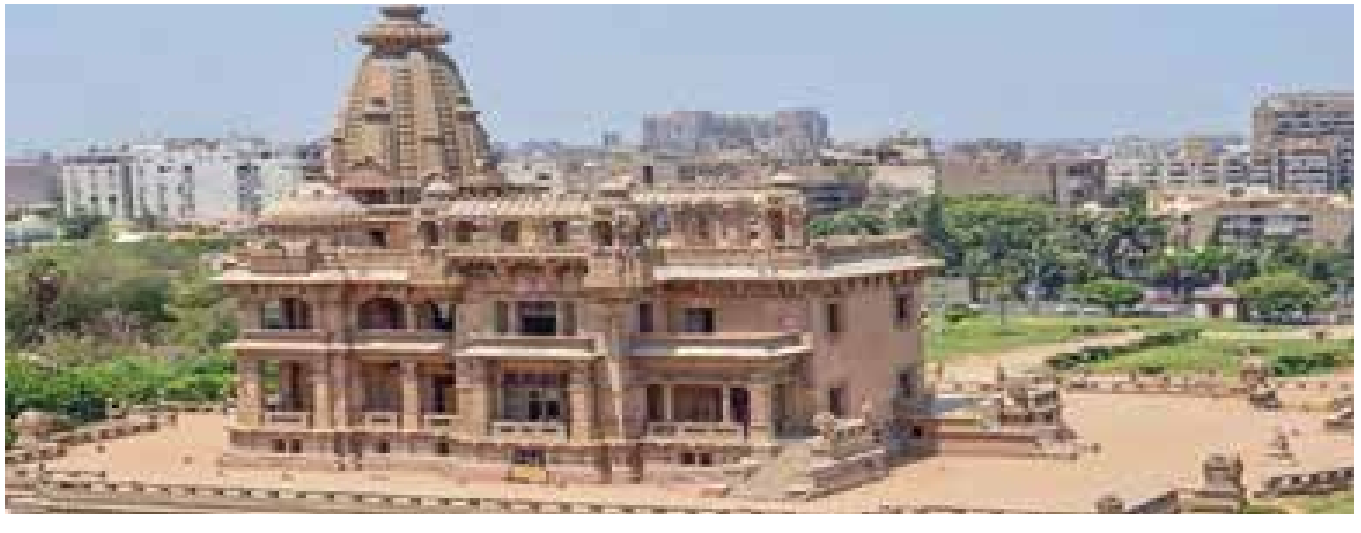

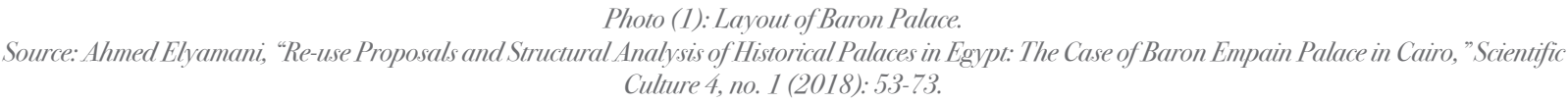

\section{Legend and Horror Stories:}

The Baron palace contains several unusual stories that can be used to create the horror tour inside it, for instance: - The myth of the Palace design on Indian mythology, the conflict between evil and goodness ${ }^{24}$

- The body of the baron's wife found in the food elevator and his sister, who fell from the top of the tower and died. Also, it is said that the Baron was interested in magic related to life after death or calling up spirits and protection from evil spirits.

- The story about the restricted room or Pink room, where he brought the spirit of his sister to ask for forgiveness for not saving her-Moreover. Empain's daughter Ann was spending a lot of time in the basement, where Ann used to burn incense, which had been smelt during those times. Moreover, what made the story more exciting was the death of the six house cleaners, consecutively in mysterious accidents that were related to Ann's $\mathrm{s}^{25}$. Besides, there is a story about the Baron's brother who was also killed in the basement.

Indeed, the stories and landmarks associated with horror locus through narratives, which means re-building an attractive image by merging fiction and reality, to increase guest's interest and attraction to horror tourism, which raises the symbolic value of places. Besides, the tour operators emphasize unique destination features by using similar techniques and discourses, technology, literary elements, movie references and hence creating horror tours by using the stories related to the sites, as follows:

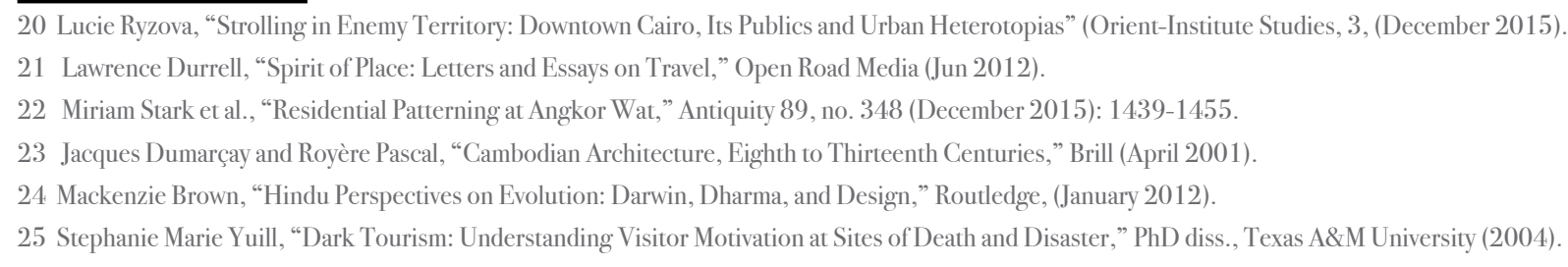




\section{Implementing Horror tourism inside the Baron Palace (Ghost tour using V/R} technology):

- Duration of the tour: 1 hour.

Location: Inside the Palace (to see the actual place where the mysterious stories happened).

Price: 150 L.E including Photos during the tour.

- Number of visitors: 10 person per tour on two groups.

- Tour details: Ghost tours provide a metaphysical interpretation of real human tragedy and turn the experience of visiting the Horror Tourism sites into a thrilling experience. So, imagine a walkabout with one of the palace's ghosts as an adventure to explain and discover the site in which tourists desire to see the places connected with rumors or mysteries spread by people to explore reality through fiction. Visitors hope to experience this adventure inside the palace to discover the actual events and connect with the place where the themes of many rumors take place. In our opinion, the film industry and the media have played an important role in the propaganda of Baron Palace myths. According to Smith $(1999)^{26}$, it is important to concentrate on the role of narrative that lifts sites in value, besides the myths and narratives that signify heroism and self-sacrifice, which promote specific areas as sites or places of mysteries. As mentioned, the auras surrounding those places produce or provoke a response within the individual to visit these sites.

\section{SWOT analysis of Horror Tourism in Egypt:}

Due to lack of studies, which dealt with the type of Horror tourism, a set of brainstorming sessions were conducted and implemented in the presence of numerous specialists and academics to discuss the weaknesses and strengths of horror tourism as well as the opportunities and challenges that may face implementation in Foypt. Additionally, considering Romania horror tourism as a reference for the study:

\section{SWOT analysis of Horror Tourism in Egypt:}

\begin{tabular}{|l|l|}
\hline \multicolumn{1}{|c|}{ Strengths } & \multicolumn{1}{c|}{ Weaknesses } \\
\hline - Diversity of horror tourism sites in Egypt. & - Lack of proper coordination between stakeholders and \\
- Egyptian heritage includes many mysterious and horror & investors. \\
stories. & - Neglect of some sites and destruction. \\
- Competitive edge for the companies. & - The stes are next to crowded suburban. \\
- Using technology in Horror Tourism scenarios. & $\begin{array}{l}\text { No clear market strategy or legislation on Horror tourism } \\
\text { in Egypt. } \\
\text { - Nearness from services. } \\
\text { - Easy to access. }\end{array}$ \\
& $\begin{array}{l}\text { Lack of awareness about horror tourism and its } \\
\text { importance. }\end{array}$ \\
\hline Opportunities & Lack of qualified services. \\
\hline
\end{tabular}

26 Anthony Smith," Myths and Memories of the Nation," Vol. 288. Oxford: Oxford University Press, (January 1999).
Horror tourism attract a new segment of visitors via using unique presentation tools such

Available opportunities to finance for reusing in horr tourism sites.

Epidemics and viruses (Covide 19).

- The human factor (vandalism)

- Terrorism, wars and crises.

Lack of qualified services.

Economics breakdown.

\section{The Study Recommends}

. Raising awareness through the Supreme Council of antiquities about Horror tourism for both domestic and foreign tourisn to visit and learn about Horror tourism, to show the importance and benefits of it.

2. The need for cooperation between the stakeholders in order to develop Horror Heritage sites.

3. Including Baron Palace as a horror heritage site the Travel agencies.

4. Creating scenarios for tours in the palace, viewing the stories related to the site

. Removing obstacles that may face Horror tourism in Egypt, as putting new lawful regulations that help implement the Horror tourism in Heritage sites.

6. Implementing Horror tourism provides several job opportunities, creates craft activities and helps attract investments in the tourism sector.

\section{Conclusion}

Sites of murders, disasters and supernatural occurrences are drawing hordes of tourists from all over the world. These sites have built around themselves an aura of mystery and intrigues like so many other places that have been witness to catastrophe and disasters. Tourism authorities around the world are now cashing in on a trend called Horror tourism; it involves travelling to places that have witnessed various human sufferings and tragedies besides sites of terrorist attacks, murders and haunted

Egypt has various sites that can be used as Horror tourism such as the Baron Palace, which has all the horror elements and stories that can be effectively utilized. Likewise, the massacre of Nohamed Aly, is also a place of the historical tragedy which can light on Horror tourism sites as a new trend in the tourism industry using the Baron Palace as a case study. 


\section{Bibliography:}

- Ali-Knight, Jane, “The Role of Niche Tourism Products in Destination Development," PhD diss., Edinburgh Napier University (2010).

- Attia, Abeer, Dalal Abd El-Hady, and Salma El-Manhaly., "The Role of Dark Tourism in Developing The Demand for The Egyptian Tourist Product," Tourism Research Institute 12, no. 1 (December 2015): 3-14.

- Beresford, Matthew, "From Demons to Dracula: The Creation of the Modern Vampire Myth, Reaktion Books (December 2008).

- Bos, Kirsten I., Verena J. Schuenemann, G. Brian Golding, Hernán A. Burbano, Nicholas Waglechner, Brian K. Coombes, Joseph B. McPhee et al., "A draft genome of Yersinia pestis from victims of the Black Death.” Nature 478, no. 7370 (October 2011): 506-510.

- Brown, C. Mackenzie, "Hindu Perspectives on Evolution: Darwin, Dharma, and Design,” Routledge, (January 2012 ).

- Candrea, Adina Nicoleta, Ana Ispas, Elena Nicoleta Untaru, and Florin Nechita, "Marketing The Count’s Way: How Dracula's Myth Can Revive Romanian Tourism,” Bulletin of The Transylvania University of Brasov. Economic Sciences. Series V 9, no. 1(September 2016): 83.

- Carter, Warren. John, Storyteller, Interpreter, Evangelist. Baker Books (Jun 2006).

- Chronis, Athinodoros, "Between Place and Story: Gettysburg as Tourism Imaginary,” Annals of Tourism Research 39, no. 4 (October 2012): 1797-1816.

- Dale, Crispin, and Neil Robinson, "Dark tourism," Research Themes for Tourism (2011): 205-217.

- Dumarçay, Jacques, and Pascal Royère, "Cambodian Architecture, Eighth to Thirteenth Centuries," Brill (April 2001).

- Durrell, Lawrence, "Spirit of Place: Letters and Essays on Travel," Open Road Media (Jun 2012).

- Elyamani, Ahmed, "Re-use Proposals and Structural Analysis of Historical Palaces in Egypt: The Case of Baron Empain Palace in Cairo," Scientific Culture 4, no. 1 (2018): 53-73.

- Inglis, David, and Mary Holmes, "Highland and Other Haunts: Ghosts in Scottish Tourism," Annals of Tourism Research 30, no. 1(January 2003): 50-63.

- Ingram, Joanne, "Volunteer Tourism: How do we know it is Making a Difference," Volunteer Tourism: Theoretical Frameworks and Practical Applications (2011): 211-222.

- Isaac, Rami K., and Vincent Platenkamp, “Dionysus versus Apollo: An Uncertain Search for Identity through Dark Tourism-Palestine as a Case Study” In the Palgrave Handbook of Dark Tourism Studies, Palgrave Macmillan, London (2018): 211-225.( refe.5)

- Lennon, J. J., and M. Foley, “Dark Tourism: The Attraction of Death and Destruction,” London: Cengage Learning EMEA (September 2000).

- Light, Duncan. The Dracula Dilemma: Tourism, Identity and the State in Romania. Routledge, 2016.

- Marson, Duncan, Duncan Marson, “From Mass Tourism to Niche Tourism,” Research Themes for Tourism (2011): 1-11.

- Powell, Raymond, James Kennell, and Christopher Barton. “Dark Cities: A dark tourism index for Europe’s tourism cities, based on the analysis of DMO websites." International Journal of Tourism Cities (March 2018).

- Pritchard, Annette, and Nigel Morgan, "Mood Marketing'-the New Destination Branding Strategy: A Case Study of Wales`The Brand, Journal of Vacation Marketing 4, no. 3 (July 1998): 215-229.

- Romania, Insider.” Dracula's Castle in Central Romania ups turn over, visitor number in 2017”, Accessed November 11th, 2020, https://www.romania-insider.com/bran-castle-turnover-visitor-2017.

- Ryzova, Lucie, "Strolling in Enemy Territory: Downtown Cairo, Its Publics and Urban Heterotopias" (Orient-Institute Studies, 3, (December 2015).

- Sharpley, Richard, and Philip R. Stone, Eds. "The Darker Side of Travel: The Theory and Practice of Dark Tourism," Channel View Publications (August 2009).( refe.1)

- Smith, Anthony D," Myths and Memories of the Nation," Vol. 288. Oxford: Oxford University Press, (January 1999).

- Stark, Miriam T., Damian Evans, Chhay Rachna, Heng Piphal, and Alison Carter., "Residential Patterning at Angkor Wat," Antiquity 89, no. 348 (December 2015): 1439-1455.

- Stone, Philip R, “A Dark Tourism Spectrum: Towards a Typology of Death and Macabre Related Tourist Sites, Attractions and Exhibitions,” Turizam: Međunarodni Znanstveno-Stručni časopis 54, no. 2 (Jun 2006): 145-160.

- Tarlow, Peter E, "Dark Tourism," Niche Tourism 47 (Jun 2007).

- Yuill, Stephanie Marie, "Dark Tourism: Understanding Visitor Motivation at Sites of Death and Disaster," PhD diss., Texas A\&M University (2004).

- Zheng, Chenguang, and Laura Lee Colgin., “A Neuronal Mechanism for Recall of Bad Events” Nature Neuroscience 20, no. 4 (April 2017): 501-503. (refe.2) 